УДК 616.89-615.212.7.099:613.814

\title{
НЕОБХІДНІСТЬ УДОСКОНАЛЕННЯ ПІСЛЯДИПЛОМНОЇ ОСВІТИ ЛІКАРІВ У СВІТЛІ ВПРОВАДЖЕННЯ НОВІТНІХ ТЕХНОЛОГІЙ ПРОФІЛАКТИКИ ВЖИВАННЯ ПСИХОАКТИВНИХ РЕЧОВИН У ДІТЕЙ ТА ПІДЛІТКІВ
}

А. М. Вісвський

Украӥнський медичний та моніторинговий цеентр з алкоголю та наркотиків МОЗ Украӥни

\section{THE NECESSITY OF MEDICAL POST-GRADUATE EDUCATION IMPROVEMENT IN CONNECTION WITH THE NEW CHILDREN DRUG PREVENTION TECHNOLOGIES IMPLEMENTATION}

\author{
A. M. Viyevskyi \\ Ukrainian Medical and Monitoring Centre on Alcohol and Drugs of MPH of Ukraine
}

\begin{abstract}
У статті висвітлені проблеми і напрямки удосконалення післядипломної підготовки лікарів, що виникають у зв'язку з впровадженням системи профілактики вживання ПАР, спрямованої на учнів 1-11 класів загальноосвітніх закладів I-III ступенів навчання. Ці новітні профілактичні технології вимагають розробки і впровадження спеціального(их) курсу(ів) тематичного удосконалення (ТУ) для лікарів - учасників профілактичної програми, в першу чергу, сімейних лікарів, педіатрів та наркологів. Покращення підготовки лікарів забезпечить обгрунтовану стабільність роботи профілактичної програми і впевненість щодо реалізації ії завдань.
\end{abstract}

The paper reflects the doctors' post-graduate education improvement problems and trends in connection with the psychoactive substances use prevention system implementation for the 1 - 11 classes pupils of the I - III levels schools. These new prevention technologies dictate the necessity of special post-graduate education course(s) elaboration and implementation for participating medical doctors, and, first of all, for GPs, pediatricians and narcologists. The medical post-graduate education improvement will give the good stable basis for further prevention program realization.

На теперішній час в Україні діє Концепція реалізації державної політики у сфері протидії поширенню наркоманії, боротьби з незаконним обігом наркотичних засобів, психотропних речовин та прекурсорів на 2011-2015 роки, що повністю базується на принципах і підходах до наркотичної політики, прийнятих Європейським Союзом, п. 2 якої передбачено “зменшення попиту та вживання наркотичних засобів, проведення дієвої первинної профілактики серед дітей та молоді; підвищення рівня поінформованості населення щодо наслідків розповсюдження наркотиків".

Профілактичні дії щодо наркотичних/алкогольних проблем серед дітей та молоді, що є частиною стратегії формування здорового способу життя на засадах розвитку життєвих навичок, координуються Міністерством освіти та науки, молоді та спорту України, за даними якого станом на 2009 рік інформаційно-профілактична освіта щодо алкоголю та наркотиків (обсягом лише $1-5$ академічних годин на рік) передбачена в навчальній програмі “Основи здоров' я" 5-9 класів загальноосвітніх закладів України. Разом з тим, (C) А. М. Вієвський необхідно відмітити, що в існуючій в країні шкільній системі освіти системна профілактика алкогольних та наркотичних проблем для школярів $1-4$ років навчання не передбачена взагалі. До того ж, результати моніторингового дослідження курсу свідчать [1], що за вісім років упровадження предмета лише 47,7 \% вчителів мають сертифікат про проходження курсової підготовки з методики викладання предмета “Основи здоров'я”. Як наслідок, лише 51 \% учнів оволоділи навичками, що сприяють безпеці в навколишньому середовищі, у інших $49 \%$ респондентів навички виявились недостатньо сформованими.

Ефективність профілактичних дій серед учнів пов'язана, передусім, із компетентністю тих дорослих, які знаходяться поряд з ними. В першу чергу, це їхні батьки та персонал школи, в якій вони навчаються. Проте в шкільній системі освіти досі відсутні систематичні структуровані профілактичні програми, зорієнтовані саме на ці контингенти населення: на батьків учнів 1 - 11 класів і персонал загальноосвітніх навчальних закладів. 
Діти та підлітки проводять значну частину свого життя саме в школі. Тому вона відіграє важливу роль у створенні умов для здобуття ними знань, формуванні ставлень та виробленні навичок, які потрібні, щоб уникнути та запобігти ризику для власного здоров'я, наприклад, пов'язаному із вживанням наркотиків. Шкільне середовище має можливості щодо мобілізації певних ресурсів: кадрове забезпечення, наявність відповідного простору, технічного оснащення, відповідних умов (час, місце, зв' язок з батьками учнів). Школа - це ефективне місце для розробки та впровадження політики щодо алкоголю та наркотиків.

З урахуванням вищезазначеного, а також того факту, що існуючі на теперішній час в Україні профілактичні заходи, орієнтовані на зниження розповсюдження серед учнівської молоді вживання психоактивних речовин (ПАР), є малоефективними [2 - 7], нами, на підставі дослідження дітей та підлітків учнів шкіл Чернівецької, Київської, Закарпатської областей та м. Києва (всього 1870 осіб), розроблена та апробована у школах вищезгаданих регіонів комплексна багаторівнева система медико-соціальної профілактики вживання ПАР у дітей та підлітків, основна ідея якої - сформувати в учнів відповідальне ставлення до власного здоров'я у профілактичній співпраці з їх батьками та персоналом школи, що базується на навчанні здорового способу життя на засадах розвитку життєвих навичок та створення можливостей впливу на основні негативні наслідки вживання дітьми ПАР, а саме - вживання зі шкідливими наслідками $[8,9]$.

Дана система містить декілька стратегічних напрямків профілактичної роботи: орієнтованої безпосередньо на дитячі контингенти (диференційованізалежно від вікової групи), на їх батьків та персонал загальноосвітніх шкіл. Профілактичнеінформування іформування навичокпрофілактичної протиалкогольної тапротинаркотичної спрямованості, що складають основу практичної частини згаданої системи, здебільшого знаходиться в площині первинної профілактики і зорієнтовані, в першу чергу, на здорові (з наркологічної точки зору) загальні контингенти школярів. Разом з тим, нами напрацьовані практичні прийоми та впливи виявились ефективними і для особливо актуальних з соціально-медичної точки зору контингентів дітей зі вживанням ПАР 3 негативними наслідками та інших ризикових контингентів іє важливимінструментарієм для вторинної профілактики алкогольних та наркотичних проблем і розладів.

Особливе місце в реалізації цієї системи заходів відведено медичним працівникам - насамперед, сімейним лікарям або працівникам педіатричної поліклінічної мережі системи MO3 України. Так, системою передбачено проведення триступеневого профілактичного консультування сімейними лікарями батьків (законних представників) дітей шкільного віку та ведення цими лікарями “Карти профілактичного моніторингу здоров'я дитини і попередження ризиків алкогольних та наркотичних проблем" (табл. 1).

Таблиця 1. Цільові профілактичні консультації сімейних лікарів для батьків (законних представників) дитини шкільного віку

\begin{tabular}{|c|c|}
\hline Тематика заходів & Результат \\
\hline \multicolumn{2}{|c|}{$\begin{array}{c}\text { Профілактична консультація № } 1 . \\
\text { батьків (законних представників) дітей віком від } 6 \text { до } 8 \text { років під час огляду дитини перед } \\
\text { иколою }\end{array}$} \\
\hline $\begin{array}{l}\text { 1. Сімейні та особистісні фактори захисту від } \\
\text { негативних наслідків вживання алкоголю та } \\
\text { наркотиків. Оцінка ї рівня. Можливості батьків } \\
\text { щодо посилення зазначених факторів захисту. } \\
\text { 2. Отримання інформованої згоди батьків на } \\
\text { підтримку заходів щодо попередження наркотичних } \\
\text { та алкогольних проблем у дитини впродовж } \\
\text { шкільних років навчання. }\end{array}$ & $\begin{array}{l}\text { Батьки ознайомлені } 3 \text { інформацією по темі } \\
\text { інтервенції, наданий профілактичний роздатковий } \\
\text { матеріал та інструменти (тест-анкети) для оцінки. } \\
\text { Дитина направлена для участі у комплексній } \\
\text { програмі } 3 \text { профілактики алкогольних та та та } \\
\text { наркотичних проблем, спрямованій на учнів, їх } \\
\text { батьків та персонал загальноосвітніх навчальних } \\
\text { закладів у_е }\end{array}$ \\
\hline \multicolumn{2}{|c|}{$\begin{array}{c}\text { Профілактична консультація № } 2 . \\
\text { Проводиться для батьків (законних представників) дітей віком від } 9 \text { до } 11 \text { років під час огляду дитини в } \\
\text { зв'язку з будь-яким захворюванням }\end{array}$} \\
\hline $\begin{array}{l}\text { 1.Фактори ризику алкогольних та наркотичних } \\
\text { проблем у підлітка та можливості батьків щодо їх } \\
\text { зменшення. } \\
\text { 2.Оцінка наявності ознак вживання підлітком } \\
\text { алкоголю чи наркотичних речовин та оцінка його } \\
\text { схильності до залежної (адиктивної) поведінки. }\end{array}$ & $\begin{array}{l}\text { Батькам наданий профілактичний } \text { роздатковий } \\
\text { матеріал та інструменти (тест-анкети) для оцінки. }\end{array}$ \\
\hline
\end{tabular}


Продовження табл. 1

\begin{tabular}{|c|c|}
\hline Тематика заходів & Результат \\
\hline \multicolumn{2}{|c|}{$\begin{array}{c}\text { Профілактична консультація № } 3 . \\
\text { диться на прохання батьків (законних представників) у підлітковому віиі дитини }\end{array}$} \\
\hline $\begin{array}{l}\text { 1. Можливості оцінки наявності } \text { у } \text { підлітка } \\
\text { алкогольної/наркотичної залежності. }\end{array}$ & $\begin{array}{l}\text { Батькам наданий профілактичний роздатковий } \\
\text { матеріал та інструмент (тест-анкета) для оцінки. } \\
\text { Можливість проведення добровільного анонімного } \\
\text { лабораторного дослідження наявності психоактивних } \\
\text { речовин у слині дитини. }\end{array}$ \\
\hline
\end{tabular}

Батьки (значимі близькі) відіграють важливу роль у формуванні навичок безпечної поведінки дитини, в тому числі в її стійкій впевненій відмові від наркотиків та алкоголю. Моделі поведінки, які батьки реалізують вдома, дають дітям сильні стимули утримуватися від наркотичних речовин чи, навпаки, провокують експериментування з ними. Батьки відіграють важливу роль у формуванні ставлення їхньої дитини до профілактичних занять, а саме: вони можуть або закріпити у дитини набуті профілактичні навички, або відвернути увагу від профілактичної діяльності своєю байдужістю, пасивністю чи агресивністю та негативізмом. Тому надзвичайно важливо, щоб батьки підтримували ефективні профілактичні заходи та брали активну участь у протинаркотичній та протиалкогольній профілактиці.

Для лікаря, який буде брати участь у створеній та апробованій нами медико-педагогічній профілактичній системі, $є$ необхідним набуття нових професійних навичок, які, звичайно, не $\epsilon$ предметом навчання у медичних ВНЗ України. Необхідність набуття таких навичок викликана використанням у згаданій профілактичній програмі низки передових профілактичних технологій. Однією з них є використання “коротких профілактичних інтервенцій (втручань)” та проведення профілактичних (спів) консультацій.

Профілактична (спів)консультація в нашому випадку - це фахове "втручання" в особисте чи сімейне життя 3 метою попередження негативних наслідків вживання алкоголю/наркотиків дитиною в межах завдань профілактичної програми, зорієнтованої на батьків учнів 1 - 12 класів і персонал загальноосвітніх навчальних закладів. Достатній рівень компетентності батьків складається не стільки з правдивих знань про алкоголь та наркотичні речовини, скільки з можливостей батьків підвищити сімейний захист та особистісний захист дитини від появи у неї цих проблем. Це вже не кажучи про те, що раннє або своєчасне виявлення фактів залежної поведінки дитини може істотно вплинути на подальший іiі розвиток завдяки своєчасному втручанню. В цьому розділі програми лікарі методологічно виконують завдання інформу- вання батьків про різноманітні ознаки вживання психоактивних речовин, оцінку рівня факторів ризику та рекомендації відносно дій батьків в таких ситуаціях, досягають інформованої згоди батьків на участь родини в профілактичній програмі, зорієнтованій на батьків учнів 1 - 12 класів і персонал загальноосвітніх навчальних закладів.

Як випливає 3 таблиці 1 , профілактична консультація № 1 проводиться для батьків дітей віком від 6 до 8 років, профілактична консультація № 2 проводиться для батьків дітей віком від 9 до 11 років, профілактична консультація № 3 - у підлітковому віці в разі потреби. Вибір саме таких вікових етапів зумовлений значним теоретичним обгрунтуванням того, що ефективність профілактичних дій залежить від своєчасного їх початку, тобто починати діяти треба до появи ризикової поведінки дитини. Іншим аргументом $€$ те, що саме початок шкільного життя дитини - це можливість для активного спілкування з її батьками та отримання від них інформованої згоди на підтримку заходів щодо попередження негативних наслідків вживання алкоголю та наркотиків впродовж років навчання дитини в школі.

Для забезпечення та алгоритмізації процесу профілактичного консультування нами створене методологічне забезпечення - супровідні матеріали, диференційовані для кожної профілактичної консультації.

Так, при профілактичній консультації № 1 лікар має використовувати "Тест-анкету для батьків дітей віком від 6 до 8 років", яка складається 3 двох блоків: "Сімейний захист щодо появи наркотичних/алкогольних проблему дитини” та “Особистісний захист щодо появи наркотичних/алкогольних проблем у дитини”, а також “Анкету щодо інформування батьків (законних представників) з питань попередження у дітей вживання спиртних напоїв та наркотичних засобів", яка має дві складові, що висвітлюють деякі уявлення батьків, що створюють додаткові ризики для дитини, та питання сімейного захисту. За запропонованим алгоритмом, лікар надає батькам інформаційний роздатковий матеріал щодо попередження негативних наслідків вживання алкоголю та нарко- 
тичних речовин дитиною та проводить профілактичну консультацію № 1, яка супроводжується фіксованим обсягом інформації такого змісту: “До системи обов’язкових медичних профілактичних оглядів учнів входять профілактичні заходи щодо попередження негативних наслідків вживання алкоголю та наркотичних речовин дитиною, в рамках яких я повинен (-на) надати Вам відповідну друковану профілактичну інформацію. Ви читаєте та аналізуєте іiі вдома. Анкета та інформаційне повідомлення "Коротко про головне” дадуть Вам можливість перевірити рівень сімейного захисту та рівень особистісного захисту дитини щодо появи проблем, пов'язаних із вживанням алкоголю та наркотиків, та підкажуть, яким чином його можна підвищити". Навички і зміст цільового консультування є принципово новою фаховою вимогою до лікаря - учасника запропонованої нами медико-педагогічної профілактичної системи.

При проведенні профілактичної консультації № 2 на допомогу лікареві створені “Тест-анкета для батьків дітей віком від 9 до 12 років”, що включає опитувальники щодо виявлення ризику наявності ознак вживання наркотичних речовин у дитини чи підлітка й стосовно того, наскільки добре батьки знають свою дитину, а також підбірка інформаційних матеріалів щодо ефективного спілкування підлітків в родинному колі, соціальних, особистісних та біологічних факторів ризику появи наркотичних й алкогольних проблем у дітей та підлітків, а також рекомендації щодо дій батьків, які підозрюють вживання наркотиків дитиною. При цьому лікар надає батькам інформаційний роздатковий матеріал щодо основних факторів ризику та ознак наявності вживання наркотичних речовин дитиною (підлітком) і проводить профілактичну консультацію № 2, яка супроводжується фіксованим обсягом інформації такого змісту: "В рамках профілактичного огляду дитини важливим є іiі ставлення до алкоголю та наркотиків, тому що підлітковий вік супроводжується ризиковою поведінкою. Ви маєте можливість звернути увагу на ризики, що можуть привести Вашу дитину до вживання і відвернути або знизити їх. Пропоную Вам відповісти на питання анкети та уважно вивчити відповідний інформаційний матеріал”.

При проведенні профілактичної консультації № 3, за бажанням батьків або іншого законного представника дитини, лікар надає інформаційний роздатковий матеріал щодо оцінки наявності у підлітка алкогольної/наркотичної залежності та проводить консультацію, яка супроводжується фіксованим обсягом інформації такого змісту: “За допомогою даних анкет та експрес-діагностики Ви маєте можливість визначити наявність алкогольної залежності та факт вживання наркотичних речовин дитиною (чи підлітком)", для чого запропонований тестовий матеріал стосовно визначення наявності алкогольної (наркотичної залежності) та алгоритм дії для батьків (законних представників), які дізналися про вживання наркотичної речовини дитиною.

Профілактичне інформування і формування навичок профілактичної протиалкогольної та протинаркотичної спрямованості, що складають основу практичної частини згаданої системи, здебільшого знаходиться в площині первинної профілактики і зорієнтовані, в першу чергу, на здорові (з наркологічної точки зору) загальні контингенти школярів. Разом з тим, напрацьовані практичні прийоми та впливи виявились ефективними і для особливо актуальних 3 соціально-медичної точки зору контингентів дітей зі вживанням ПАР з негативними наслідками та інших ризикових контингентів іє важливим інструментарієм для вторинної профілактики алкогольних та наркотичних проблем і розладів.

Такимчином, враховуючи багатокомпонентність ірізноманітність впливів, що передбачаються даною системою заходів, місце в ній сімейного лікаря або педіатра є незамінним та вкрай важливим, бо саме профілактичний моніторинг тапрофілактичне консультування батьків, що має здійснювати сімейний лікар/педіатр, є інтегруючим базисом для здійснення усіх інших заходів комплексної багаторівневої системи профілактики вживання психоактивних речовин у дітей та підлітків.

Кожний етап шкільних років дитини має відповідні до віку ризики, знання яких є важливою частиною адекватної теоретичної підготовки лікарів, що в силу своїх функціональних обов'язків беруть участь у профілактичній програмі. Згадані вище ризики можуть бути прямі та непрямі, соціальні та особистісні. Звичайно саме підлітковий вік визначається піком ризикованої поведінки людини, але це ще більше підтверджує факт про важливість початку профілактичних дій раніше, серед учнів початкових класів. В умовах школи період пізнього дитинства та ранній підлітковий період (6-13 років) є вирішальними моментами для можливості сформувати корисні навички та вміння. В ці періоди життя діти розвивають здатність думати абстрактно, розуміти наслідки, співвідносити себе з ровесниками по-новому, розв' язувати проблеми, відчувати себе більш незалежними від батьків і більше контролюють власне життя.

Відповідно тематичні блоки програми розроблені 3 урахуванням вікових особливостей учнів, а саме: 
1. Уроки для учнів першого ступеня навчання мають профілактичне спрямування з акцентом на понятті “Моє здоров'я” (навички підтримки здорового способу життя). Учні вчаться відрізняти корисне від шкідливого, безпечне від небезпечного.

2. Уроки для учнів другого ступеня навчання мають профілактичне спрямування з акцентом на понятті “Моє рішення” (навички прийняття рішення та критичне мислення). Учні пізнають себе і те, що на них впливає. Аналізуючи інформацію про ПАР, вони вчаться розрізняти факти від міфів, приймати усвідомлені рішення в ситуаціях ризику.

3. Уроки для учнів третього ступеня навчання мають профілактичне спрямування з акцентом на понятті “Мій вибір” (самовизначення та власна життєва позиція). Учні аналізують різні “сценаріі”' життя людей, які обрали шлях вживання наркотиків чи алкоголю. Визначаються 3 власною життєвою позицією, цінностями. Вчаться відстоювати свої переконання та погляди. Будують свій власний “сценарій життя” на основі питань: хто я є і ким я хочу бути?

Важливе місце в профілактичній програмі належить досягненню таких цілей:

- мотивування учнів на активну взаємодію під час занять;

- включення у роботу в загальній та малих групах;

- зацікавленість тематичним матеріалом та можливість його ефективного засвоєння.

Дослідники вважають, що коли молодь має можливість активно взаємодіяти, практикувати навички у безпечній атмосфері шкільного класу, вони будуть готові користуватися цими ж навичками поза межами школи. Навчання з активною участю учнів використовує досвід, думки й знання членів групи, створює продуктивну атмосферу творчості для розкриття та розвитку можливостей і альтернатив, а також пропонує джерело взаємного комфорту й безпеки, що допомагає процесу навчання та прийняття рішення.

Якщо учні сформували адекватне ставлення щодо вживання наркотиків та алкоголю і засвоїли навички особистісної та соціальної компетентності, вони краще підготовлені до ухвалення розумного, свідомого рішення і вибору поведінки в ситуаціях, пов' язаних 3 ризиком щодо вживання психоактивних речовин. Глибинне розуміння лікарем інтерактивних можливостей впроваджуваної профілактичної системи, як і досконале знання теоретичного обгрунтування профілактичного курсу, є його наріжними каменями.

Теоретичним обгрунтуванням створеного профілактичного курсу є оригінальна комбінація сучасних соціально-психологічних поглядів, а саме:
1. Теорія соціального навчання.

Навчання навичок потребує відтворення природних процесів, у яких діти вчаться поводитися: моделювання, спостереження та соціальна взаємодія.

2. Теорія проблемної поведінки.

Поведінка підлітків є результатом складної взаємодії між людьми та їх оточенням. На форми поведінки впливають цінності, ставлення особи, сприйняття друзями і родиною цих типів поведінки. Таким чином, навички критичного мислення (включно із здатністю оцінювати себе та цінності соціального середовища), ефективного спілкування та переговорів $\epsilon$ важливими аспектами навчання здорового способу життя на засадах розвитку життєвих навичок.

3. Теорія соціального впливу та соціального щеплення.

Діти та підлітки підпадають під тиск щодо залучення до ризикованої поведінки. Тиск однолітків та соціального середовища щодо участі в нездорових формах поведінки можна перебороти шляхом вирішення проблеми тиску до того, як дитина чи підліток стануть об'єктом тиску. Таким чином йдеться про профілактичне спрямування на ранній стадії, а не про втручання на пізній. Формування у дітей навичок опору є більш ефективними для зменшення проблемної поведінки порівняно з наданням інформації чи спробами викликати страх перед результатами такої поведінки.

4. Теорія когнітивного розв' язання проблеми.

Навчання дітей навичок соціально-когнітивного розв'язання проблем може покращити міжособистісні стосунки та контроль імпульсивності, сприяти прийняттю підлітками самозахисних та взаємно вигідних рішень, а також зменшити чи запобігти негативним для здоров’я формам поведінки.

5. Теорія пружності.

Взаємодія деяких зовнішніх та внутрішніх факторів дозволяє людям подолати проблеми. До таких внутрішніх захисних факторів належать самооцінка та впевненість у собі, самоконтроль та відчуття змісту життя, а до зовнішніх - головним чином підтримка з боку родини та громади.

Цілісне розуміння лікарем створеної профілактичної системи, як і знання її складових на рівні з їі іншими складовими і практичними елементами повинні стати одночасно новою і вкрай необхідною частиною післядипломної підготовки лікаря - учасника загальнодержавної медико-педагогічної профілактичної програми. Іншим безпосереднім виконавцем згаданого профілактичного курсу є класний керівник 111 класів у загальноосвітньому навчальному закладі. 
Запроваджувані профілактичні уроки для учнівської молоді вводяться, як невід'ємна частина, в систему виховних позакласних годин класного керівника. Кількість профілактичних уроків в початкових класах дорівнює 4-м урокам на один навчальний рік. 35 по 11 клас кількість таких уроків складає 8 на один навчальний рік. Тривалість одного профілактичного заняття - 45 хв. Така кількість занять і їх тривалість не перевантажує встановлений режим роботи вчителя та учня в умовах навчально-виховного процесу.

Профілактичний урок складається з етапів, і кожний етап профілактичного уроку є важливим для засвоєння тематичного матеріалу.

Етапи профілактичного уроку:

1. Актуалізація теми.

2. Тематичний блок.

3. Підсумок уроку.

4. Домашнє завдання.

Актуалізація теми - це не просто вступ до головних питань уроку. В даному курсі це ще й мотивування учнів на роботу, активізація мозкової діяльності, уваги, закріплення попередньо набутих знань, шляхом їх поєднання з питаннями теми даного уроку.

Тематичний блок - етап урокі, який поєднує в собі профілактичне інформування і навчання. Відповідно до вікової групи учнів, з метою ефективного засвоєння порушених в темі питань, використовуються тематичні ігри, цікаві завдання в усній та письмовій формі, ілюстративний та демонстративний матеріал. Тематичні блоки базуються на побудові логічної моделі, яка відповідає загальним цілям програми профілактики в цілому, фокусується на формуванні поведінки, від якої залежить успішне досягнення мети.

Демонстраційний матеріал, який використовується під час профілактичної роботи, можна напрацювати таким чином:

- провести серед учнів конкурс на кращий малюнок і далі користуватися ним в ході занять або використовувати усі малюнки по черзі;

- намалювати самостійно усі малюнки;

- якщо є можливість, можна скористатися послугами художника або Інтернету.

Підсумок уроку відбувається з обов'язковим використанням інтерактивних методик (наприклад, “подивіться один на одного та подаруйте трішки гарного настрою - посмішку") і застосуванням дидактичного методу - повторення тематичного матеріалу (висновки уроку).

Домашнє завдання профілактичного уроку несе в собі особливе значення, оскільки спрямовується не тільки на учня, а й на його батьків. Програма дозво- ляє активно залучити батьків до родинного обговорення тем, що стосуються алкоголю, наркотиків, ризикованої поведінки. В кінці кожного профілактичного уроку вчитель просить учнів виконати домашнє завдання, яке знаходиться в робочому зошиті в рубриках “Виконай разом з батьками”, “Заповни анкету вдома", "Питання для обговорення в родинному колі”. Завдання мають тематичний контекст і певні профілактичні цілі: залучення батьків до профілактики ризикованої поведінки та наркотичних/алкогольних проблем у їхньої дитини; активізація уваги батьків в питаннях спілкування 3 дитиною; закріплення корисних знань, шляхом розмови з батьками про їхній досвід та погляди.

Як зазначалося, створена комплексна багаторівнева система медико-соціальної профілактики вживання ПАР у дітей та підлітків врахувала також і вікову специфіку дітей. Як наслідок, ще однією групою знань для лікарів - учасників є знання і навички щодо:

- специфіки профілактичної роботи з учнями $1-4$ класів.

У початкових класах діти слухають, спостерігають та використовують знання. Провідною діяльністю даного віку є навчання. У міру досягнення віку, що відповідає навчанню у середніх класах, змінюється спосіб навчання. Діти починають "просіювати" інформацію та співвідносять ії з власним досвідом, але вірять в те, що вчитель знає найкраще. Вони більше навчаються через осмислення та розв'язання проблеми, ніж через слухання, та бажають взаємодіяти із джерелом інформації. Під час профілактичної роботи необхідно уникати будь-якого ненавмисного стимулювання привабливості теми наркотиків та алкоголю;

- специфіки профілактичної роботи з учнями 5- 9 класів.

Провідна діяльність раннього підліткового віку (1014 років) - інтимно-особистісне спілкування в життєдіяльності та навчанні. Психічні новоутворення: почуття дорослості, прагнення до самостійності. Критичність мислення, схильність до рефлексії, формування самоаналізу, потреба у спілкуванні, оцінювання товариських та дружніх стосунків як особистісні досягнення. Вік характеризується статевим дозріванням, сексуальними переживаннями, інтересом до протилежної статі, підвищеною збудженістю, швидкою зміною настрою, неврівноваженістю. Помітний розвиток вольових якостей, потреба в самоствердженні, діяльності, яка має особистісний сенс.

Молодь найбільш скептична у сприйнятті інформації, схильна заперечувати загальновизнані норми $і$ 
положення. Проте зацікавлена і легко захоплюється новаціями, має високий рівень навіюваності. В молодіжній аудиторії не правильним буде оминати гострі та незручні питання, тому що це викличе критику і недовіру з боку аудиторії. У важких, дискусійних ситуаціях можна використовувати гумор. Більш детальна інформація щодо інтерактивної взаємодії з учнівською молоддю міститься в програмному модулі “Технологія проведення профілактичного тренінгу в шкільному середовищі”;

- специфіки профілактичної роботи з учнями 10-11 класів.

Провідна діяльність в ці роки - навчально-професійна шкільна діяльність (ціннісно-орієнтаційна). Психічні новоутворення: інтенсивність формування особистості (суджень, оцінок, принципів, ідеалів, переконань), самосвідомість, самовизначення, прагнення до самовиховання, самопізнання, самовдосконалення, критичне ставлення до дорослих, філософсько-романтичний світогляд, психосексуальні орієнтації, формування громадських прав та обов'язків.

\section{Література}

1. Лист Інституту інноваційних технологій змісту освіти МОН України №14/18-1274 від 30.03.2010.

2. Зріз наркотичної ситуації в Україні (дані 2010 року)/ [А. М. Вієвський, М. П. Жданова, С. В. Сидяк та ін.]. - Київ, 2011. $-22 \mathrm{c}$.

3. Медико-социологические аспекты характеристики токсикоманий у лиц подросткового и молодого возраста / С. И. Табачников, Е. Н. Харченко, Г. А. Приб [и др.] // Архів психіатрії.-2011.-Т. 17, №3 (66). -С. 61 - 66 .

4. Молодь за здоровий спосіб життя : щорічна доповідь Президенту України, Верховній Раді України, Кабінету Міністрів України про становище молоді в Україні (за підсумками 2009 р.) / Міністерство України у справах сім'ї, молоді та спорту, Державний інститут розвитку сім’ї та молоді.-К. : ТОВ “Основа”, 2010.

5. Молодь та молодіжна політика в Україні : соціальнодемографічні аспекти / за ред. Е. М. Лібанової. - К. : Інсти-
Таким чином, узагальнюючи вищевикладене, важливо підкреслити, що розроблена система профілактики вживання ПАР у дітей та підлітків, спрямована на учнів 1-11 класів загальноосвітніх закладів I-III ступенів навчання, широко використовує найсучасніші практики для досягнення поставленої мети. Ці новітні профілактичні технології вимагають розробки і впровадження спеціального курсу тематичного удосконалення (ТУ) для лікарів - учасників профілактичної програми, в першу чергу, сімейних лікарів, лікарівпедіатрів та наркологів. Нові знання обгрунтовано гарантують стабільність роботи профілактичної програми і впевненість у реалізації обох ії головних завдань: викликати рефлексію у батьків через опосередковане мотивування їх на участь у програмі, a також формування в учня власної життєвої позиції щодо ризикованої поведінки та вживання ПАР.

Враховуючи ефективність апробації даної системи в пілотних регіонах, на сьогодні проводиться робота щодо впровадження вищезазначеної системи на державному рівні.

тут демографії та соціальних досліджень ім. М. В. Птухи НАН України, 2010. - 129 с.

6. Рівень і тенденції поширення тютюнокуріння, вживання алкоголю та наркотичних речовин серед учнівської молоді України / [О. М. Балакірєва (кер. авт. кол.), Т. В. Бондар, Н. О. Рингач та ін.]. - К. : УІСД ім. О. Яременка, 2008. $152 \mathrm{c}$.

7. Комплексна програма 3 профілактики наркотичних та алкогольних проблем, зорієнтована на учнів 1-12 класів, їх батьків та персонал загальноосвітніх закладів I-III ступенів навчання : загальне викладення програми профілактичних дій / [А. М. Вієвський, К. І. Лепеха та ін.]. - Київ, 2010. -40 с.

8. Комплексна програма 3 профілактики наркотичних та алкогольних проблем, зорієнтованих на учнів 1-12 класів, їх батьків та персонал загальноосвітніх закладів I-III ступенів навчання/[А. М. Вієвський, К. І. Лепеха, В. В. Дивак та ін.]. -К. : Версо 04, 2010. - [у 17 кн.]. 